\title{
Graduate employment outcomes for qualifying library and records management courses at Curtin University of Technology, 1998-2002
}

\author{
By \\ Paul Genoni \\ Kerry Smith \\ Department of Media and Information \\ Curtin University of Technology
}

This paper reports on the results of a survey of graduate destination outcomes for students from librarianship and records management courses at Curtin University of Technology for the period 1998-2002. The coverage of the survey includes the type of work currently being undertaken by graduates, the security of tenure in their position, the level of professionalism in their employment, and their general employment history since completing their qualifying course. Further data records respondents perceptions of the importance of their qualificiation in gaining their current employment, the relationship between the skills acquired during the course and their employment, and their general level of satisfaction with the course. The results of this survey are compared with similar data previously recorded for the graduating classes of 1988-92 and 1993-97.

\section{Introduction}

This paper reports on the most recent component of a longitudinal study of employment outcomes for students completing Information Studies courses at Curtin University of Technology. The population for the first survey was drawn from students completing courses from 1988-1992; the second survey covered graduates from 1993-1997; and the survey reported here was conducted in 2004, and covered graduates from 1998-2002. Each of the surveys was delayed by some 18 months following the most recent course completions in order to allow graduating students sufficient time to find employment. The results of the two previous surveys were reported in Genoni, Exon \& Farrelly (2000).

\section{Recent research into LIS graduate destinations}

Genoni et al., (2000) reviewed the relevant literature to 1999. Marcella \& Baxter (1998) have since reported on the career progression of four cohorts of graduates from postgraduate courses in Information Analysis offered at the Robert Gordon University in the UK. While the course content offers little parallel to the course content of the Curtin studies reported in this paper, Marcella \& Baxter identified the increasing range of employment opportunities for information studies professionals in the UK. They also provide a summary of previous career surveys carried out in the library and information science (LIS) sector in the UK.

Aina \& Moahi (1999) reported on the relevance of training received by graduates of the Department of Library and Information Studies at the University of Botswana. The findings concentrated on satisfaction levels of the educational programs undertaken and indicated that although eight different programs are studied, the 
majority of graduates came from certificate and diploma courses. However, "(s)urprisingly, certificate and diploma holders were involved in managerial functions" (p. 228). Over half of the respondents indicated dissatisfaction in their current library job with the reasons being low salary, low profile in the organisation, no prospects for promotion, and lack of excitement and challenge.

Moreiro (2001) reported that in a study of Spanish library and information science graduates, originally conducted in 1995 with a follow-up survey covering graduates for the period 1996-99, the trend of fellowships as the prevailing vehicle for hiring students was apparent. It was noted that, "fellowships and temporary work accounted for over $60 \%$ of the jobs held by students” (p. 34) while they were still studying. The types of positions they occupied once graduated are not covered in this paper, although it was noted that "internships and fellowships [have become] the means of selecting personnel for businesses” (p. 34).

The longitudinal model has been used by Yakel (2003) and includes demographic comparisons between graduates of archival studies, history and LIS in the US. Students from archives education programs from 14 LIS schools responded to this national survey which, while concentrating on demographic and educational outcomes, also gave some attention to graduate employment. There is some relevance in this data to the Curtin University study because of the records management and archives unit offerings in the programs. Yakel found that the chief employing sector of the US archives graduates was the educational sector (colleges and universities) which was also responsible for employing a significant number of the LIS graduates. Low numbers of archival graduates enter the corporate sector with poor employment prospects for archivists in the museum sector.

Pember's (2003) study of records management graduates at Curtin University for the period 1992-2000 revealed that the employment rate was ninety-eight percent, with most graduates occupying permanent positions or continuing contracts. Pember did not report on the types of jobs these graduates held.

Willard, Wilson \& Cole (2003) expand on previous work and report data on the employment experiences of graduates of the University of New South Wales LIS programs for the period 1997-2001. In particular their survey focused on job descriptions and functions. The findings indicated that $25.8 \%$ of respondents occupied 'librarian' positions in their first positions utilising information management skills. Another commonly held position was 'information officer' (16.1\%), and there were individual cases where new and non-standard job titles were being used (e.g. web manager, network officer, data controller). They concluded that $71 \%$ "took positions which conveyed a connection to a library or information centre" (p. 215).

\section{The survey}

The survey instrument, in the form of a questionnaire, was developed in close alignment with that used in the earlier surveys. The one significant change made was necessary to provide for the addition of a new course - the Bachelor of Arts (Librarianship and Corporate Information Management) (hereafter BA(LCIM)). The survey consisted of three sections, headed 'Details of study at Curtin University', 
'Current employment' and 'Employment history', with supplementary questions relating to the graduate's level of satisfaction with their completed course.

The survey was directed at graduates of first qualifying courses in information and library studies for the period 1998-2002. The survey covered a five year period in order to provide consistency in the longitudinal scale of data collection with the two previous Curtin LIS surveys. Since administering the previous survey the discipline area of Information Studies (comprising instruction in librarianship, records management and archives) had undergone two major changes within the University's academic structure. The first of these in 2000 saw it placed within a new School of Media and Information, and in 2003 it became part of a Department of Media and Information within the Faculty of Media, Society and Culture. These changes in turn had an influence on the structure and content of courses.

Five first qualifying courses were offered during the survey period: a Bachelor of Applied Science in Information and Library Studies, a Bachelor of Applied Science in Records Management, a Graduate Diploma each in Information and Library Studies and in Records Management, and a new BA (LCIM). The two Bachelor of Applied Science degrees were being phased out in favour of the new BA (LCIM), which qualifies graduates to work as both librarians and records managers.

While the survey indicates five degree pathways for a first professional qualification in information and library studies, there were thirteen different degree streams which either offered a first or component qualification. These included masters programs and undergraduate double degrees, although there were very small enrolments in the double degree programs. The complexity of choice of degree programs in which students could study meant that ascertaining those students who had completed a first professional qualification was problematic. A number of student records were reviewed manually for applicability, but it is possible that some were nevertheless omitted.

After the relevant ethics and University approvals were received, the survey was distributed to all identified graduates from these courses for the relevant period. Distribution was by post using last known residential addresses acquired from the University's student records. Under these circumstances it was inevitable there would be some graduates who did not receive a survey due to a change of address.

The survey was mailed in July 2004 with a covering letter explaining the purpose of the study, addressing ethics matters including confidentiality, and requesting that questionnaires be returned within two weeks. A total of 338 questionnaires were posted, reflecting the number of graduates in a first professional qualification from Information Studies during the five year period, as shown in Table 1. 
Table 1: Number of questionnaires despatched.

\begin{tabular}{|l|c|}
\hline \multicolumn{1}{|c|}{ Degree Title } & $\begin{array}{c}\text { No of questionnaires } \\
\text { despatched }\end{array}$ \\
\hline $\begin{array}{l}\text { Bachelor Applied Science (Records } \\
\text { Management) }\end{array}$ & 24 \\
\hline $\begin{array}{l}\text { Bachelor Applied Science (Inf. and } \\
\text { Library Studies) }\end{array}$ & 114 \\
\hline $\begin{array}{l}\text { Bachelor of Arts (Media \& Information) } \\
\text { [BA (LCIM)] }\end{array}$ & 12 \\
\hline Graduate Diploma (Records Management) & 30 \\
\hline Graduate Diploma (Inf. \& Library Studies) & 135 \\
\hline Master of Information Management & 20 \\
\hline Double degrees & 3 \\
\hline Total & $\mathbf{3 3 8}$ \\
\hline
\end{tabular}

By the return date 92 completed questionnaires had been received. A better response was considered desirable and a follow up letter was therefore sent to all of the initial recipients, except for those for whom the first survey had been 'returned to sender'. It was necessary to send this letter to all other recipients, since responses were anonymous and there was no way of registering those who had previously returned the questionnaire. On this occasion a final response date was not set. The survey period was closed at the end of August 2004, and at this point all responses were compiled and processed using SPSS statistical software.

The final number of responses received was 113, representing $36.6 \%$ of those that were useable. Twenty nine of the questionnaires were returned unopened as address unknown. The numbers of questionnaires despatched, returned to sender and replied for the three survey periods are shown in Table 2.

Table 2: Responses to surveys

\begin{tabular}{|l|c|c|c|c|}
\hline Survey date & $\begin{array}{c}\text { Total } \\
\text { despatched }\end{array}$ & $\begin{array}{c}\text { Returned to } \\
\text { sender }\end{array}$ & $\begin{array}{c}\text { Replies } \\
\text { received }\end{array}$ & $\begin{array}{c}\text { \% of useable } \\
\text { surveys }\end{array}$ \\
\hline $1988-1992$ & 419 & 27 & 159 & 40.6 \\
\hline $1993-1997$ & 367 & 44 & 157 & 48.6 \\
\hline $1998-2002$ & 338 & 29 & 113 & 36.6 \\
\hline
\end{tabular}

The response rate was considered satisfactory, although it is noted that it was lower than that achieved by the previous surveys.

\section{Survey results}

\section{Courses completed}

The first section consisted of questions relating the respondent's completed course of study. The patterns of enrolment for responding graduates are shown in Table 3. 
Table 3: Qualifying course completed by respondents

\begin{tabular}{|l|c|c|c|c|}
\hline \multicolumn{1}{|c|}{ Course } & $\begin{array}{c}\mathbf{1 9 9 8 - 2 0 0 2} \\
\boldsymbol{n}\end{array}$ & $\begin{array}{c}\mathbf{1 9 9 8 - 2 0 0 2} \\
\mathbf{\%}\end{array}$ & $\begin{array}{c}\mathbf{1 9 9 3 - 9 7} \\
\mathbf{\%}\end{array}$ & $\begin{array}{c}\mathbf{1 9 8 8 - 9 2} \\
\mathbf{\%}\end{array}$ \\
\hline $\begin{array}{l}\text { B. App. Sc. (Inf \& } \\
\text { Lib Stud) }\end{array}$ & 50 & 44.2 & 54.5 & 42.7 \\
\hline $\begin{array}{l}\text { B. App. Sc. (Rec } \\
\text { Mgmt) }\end{array}$ & 12 & 10.6 & 6.5 & n/a \\
\hline $\begin{array}{l}\text { Grad Dip (Inf \& } \\
\text { Lib Stud) }\end{array}$ & 38 & 33.6 & 33.1 & 57.3 \\
\hline $\begin{array}{l}\text { Grad Dip (Rec } \\
\text { Mgmt) }\end{array}$ & 10 & 8.8 & 5.8 & n/a \\
\hline BA (LCIM) & 3 & 2.7 & n/a & n/a \\
\hline Totals & $\mathbf{1 1 3}$ & $\mathbf{1 0 0 . 0}$ & $\mathbf{1 0 0 . 0}$ & $\mathbf{1 0 0 . 0}$ \\
\hline
\end{tabular}

$\mathrm{n} / \mathrm{a}=$ data not available as these courses were introduced subsequently

Of the respondents 65 (57.5\%) completed their studies at the undergraduate level and $48(42.5 \%)$ at graduate diploma level. In terms of their area of specialisation, 88 (77.9\%) were qualified as librarians, and 22 (19.5\%) as records managers.

In addition, three (2.6\%) respondents had completed the BA (LCIM), and were therefore qualified as both librarians and records managers. The BA (LCIM) is a new degree stream, combining the studies of librarianship and corporate information (records) management. It commenced in 2000, replacing the two B. App. Sc. programs, and the first graduates completed in 2002. Data presented in this paper which distinguishes between librarianship and records management graduates omits this small group of dual-qualified respondents.

Age of graduates

The mature age of graduates, as described in Genoni et al., (2000) is again exemplified in the data from the most recent survey, the results of which are shown in Table 4.

Table 4: Age at completion of course

\begin{tabular}{|l|c|c|c|}
\hline \multicolumn{1}{|c|}{ Age } & $\begin{array}{c}\mathbf{1 9 9 8 - 2 0 0 2} \\
\boldsymbol{n}\end{array}$ & $\begin{array}{c}\mathbf{1 9 9 8 - 2 0 0 2} \\
\mathbf{\%}\end{array}$ & $\begin{array}{c}\mathbf{1 9 9 3 - 1 9 9 7} \\
\mathbf{\%}\end{array}$ \\
\hline up to 21 & 6 & 5.3 & 6.4 \\
\hline $22-24$ & 7 & 6.2 & 11.5 \\
\hline $25-34$ & 28 & 24.8 & 23.6 \\
\hline $35-40$ & 26 & 23.0 & 36.3 \\
\hline $41-50$ & 39 & 34.5 & 18.5 \\
\hline $51+$ & 7 & 6.2 & 3.8 \\
\hline Totals & $\mathbf{1 1 3}$ & $\mathbf{1 0 0 . 0}$ & $\mathbf{1 0 0 . 0}$ \\
\hline
\end{tabular}

The figures indicate that the information professions attract a decidedly mature age group of students. Of the respondents to the current survey $63.7 \%$ of those achieving a first graduating qualification were over 35 years of age. Obviously this has 
implications for their longevity in the workplace and the ability of the profession to replace retirements. This data represents a shift from the 1993-97 survey when 'only' $58.6 \%$ of respondents were over 35. It might be noted that the distribution method using the last known address may favour responses from older graduates, if it is assumed that younger graduates are likely to be more mobile and change address more frequently.

These figures can be compared with the current Australian Bureau of Statistics (ABS) data, which indicates that $80.9 \%$ of librarians are over 35 years, as compared to $58.2 \%$ for the general workforce (ABS, 2005b). This higher ABS figure is to be expected given that it includes all librarians and not only recent graduates. Taken together, however, these two sets of data suggest that the information professions are not only troubled by an aging workforce, but a workforce that is already decidedly mature as it enters the profession.

\section{Current employment status}

The employment of graduates was addressed in the second section of the survey. This included a question in which respondents were asked to report on whether they were currently in work, and if so the nature of their employment with regard to being full or part time. Results are presented in Table 5.

Table 5: Current employment status

\begin{tabular}{|l|c|c|c|c|}
\hline \multicolumn{1}{|c|}{$\begin{array}{c}\text { Current } \\
\text { employment }\end{array}$} & $\begin{array}{c}\mathbf{1 9 9 8 - 2 0 0 2} \\
\mathbf{n}\end{array}$ & $\begin{array}{c}\mathbf{1 9 9 8 - 2 0 0 2} \\
\mathbf{\%}\end{array}$ & $\begin{array}{c}\mathbf{1 9 9 3 - 9 7} \\
\mathbf{\%}\end{array}$ & $\begin{array}{c}\mathbf{1 9 8 8 - 9 2} \\
\mathbf{\%}\end{array}$ \\
\hline Working full-time & 79 & 70.5 & 68.1 & 60.9 \\
\hline $\begin{array}{l}\text { Working part-time } \\
\text { by choice }\end{array}$ & 21 & 18.8 & 14.6 & 19.9 \\
\hline $\begin{array}{l}\text { Working part-time } \\
\text { prefer full-time }\end{array}$ & 5 & 4.5 & 8.3 & 5.8 \\
\hline $\begin{array}{l}\text { Unemployed and } \\
\text { looking for work }\end{array}$ & 5 & 4.5 & 4.5 & 8.3 \\
\hline $\begin{array}{l}\text { Unemployed and } \\
\text { not looking for work }\end{array}$ & 1 & 0.9 & 1.3 & 3.2 \\
\hline Studying full-time & 1 & 0.9 & 3.2 & 1.9 \\
\hline Totals & $\mathbf{1 1 2 *}$ & $\mathbf{1 0 0 . 0}$ & $\mathbf{1 0 0 . 0}$ & $\mathbf{1 0 0 . 0}$ \\
\hline
\end{tabular}

* Missing cases: 1

These figures indicate an encouraging increase in the workforce participation of graduates. If 'satisfactory employment' is measured by the numbers engaged in either full time work or part time work by choice, then this measure has risen from $80.8 \%$ (1988-92); 82.7\% (1993-97); to 89.3\% in the current survey period. These increases in employment have been matched by corresponding decreases in those graduates either looking for work, or looking to increase their work from part-time to full-time.

It might be speculated that these results overstate the employment outcomes, if it is assumed that those who are successfully settled in a career are more likely to respond to the survey than those who have been dissatisfied with the employment outcome. 
Nevertheless the trend over the course of the three surveys is encouraging and represents an improved rate of workforce participation.

Table 6: Type of work, all graduates

\begin{tabular}{|l|c|c|c|c|}
\hline Type of work & $\begin{array}{c}\mathbf{1 9 9 8 - 2 0 0 2} \\
\mathbf{n}\end{array}$ & $\begin{array}{c}\mathbf{1 9 9 8 - 2 0 0 2} \\
\mathbf{\%}\end{array}$ & $\begin{array}{c}\mathbf{1 9 9 3 - 1 9 9 7} \\
\mathbf{\%}\end{array}$ & $\begin{array}{c}\mathbf{1 9 8 8 - 1 9 9 2} \\
\mathbf{\%}\end{array}$ \\
\hline Librarianship & 66 & 61.7 & 62.6 & 69.2 \\
\hline $\begin{array}{l}\text { Records } \\
\text { management }\end{array}$ & 18 & 16.8 & 7.9 & 10.5 \\
\hline Archives & 5 & 4.7 & 5.0 & 0 \\
\hline $\begin{array}{l}\text { Computing \& } \\
\text { Info Systems }\end{array}$ & 1 & 0.9 & 2.9 & 1.5 \\
\hline $\begin{array}{l}\text { Other } \\
\text { information } \\
\text { work }\end{array}$ & 11 & 10.3 & 12.2 & 9.0 \\
\hline $\begin{array}{l}\text { Unconnected } \\
\text { with } \\
\text { information }\end{array}$ & 6 & 5.6 & 9.4 & 9.8 \\
\hline Totals & $\mathbf{1 0 7 *}$ & $\mathbf{1 0 0 . 0}$ & $\mathbf{1 0 0 . 0}$ & $\mathbf{1 0 0 . 0}$ \\
\hline
\end{tabular}

*Missing cases, including those not currently in work: 6

In considering the area of the work the employed respondents were undertaking, it was found that the majority (61.7\%) were employed in librarianship, with $16.8 \%$ in records management and $4.7 \%$ in archives. Of the remaining $16.8 \%, 10.3 \%$ were in 'other information related work', and $5.6 \%$ were working in environments not connected with information. The 17 respondents who were working in either 'other information related work' or 'work unconnected with information handling' were asked to describe the nature of their work. Of the nine who were in 'other information related work', their descriptions of their current employment included:

'Research assistant, tasks include proofreading, editing, grant applications, information searches, compiling statistics.'

'Project management including records management projects and activities.'

'Assistant local historian/curator. Involves library skills.'

'Medical research.'

'Research.'

'Assisting partner in chemistry consultancy.'

'Bibliographic research and project management.'

'Mainly work as a clerk but have recently done more library work.'

'Administration - secretarial, research.'

Five of these nine respondents include the word 'research' in their descriptions of their current jobs. Of these nine, five indicated elsewhere in the survey that their completed course was 'extremely useful in finding work which satisfies me'; three that it had 'contributed to my finding work but not wholly to my satisfaction'; and one that it 'has contributed little or nothing to my employment'. While inconclusive, these responses suggest that graduates are prepared to look beyond traditional library and information jobs, and appreciate that the skills they acquire in the course are transferable to other occupational groups. 
Of the six respondents who are currently in 'work unconnected with information handling', four indicated they work in the education and training sectors ('TAFE lecturing'; 'vocational education and training officer'; 'manager of training services'; 'secondary school teacher'). Several of the responses in this category apparently represent failed career changes - for example one responded with, 'casual merchandising and retail, the same job I had at the beginning of the course'. Not surprisingly this group was less convinced of the value of the course, with only one indicating it was 'extremely useful in finding work which satisfies me'. Two others replied that it had 'contributed to my finding work but not wholly to my satisfaction'; and three that it 'has contributed little or nothing to my employment'.

It is useful to consider these results separately for the two professional groups.

Table 7: Type of work, librarianship graduates

\begin{tabular}{|l|c|c|c|c|}
\hline Type of work & $\begin{array}{c}\mathbf{1 9 9 8 - 2 0 0 2} \\
\mathbf{n}\end{array}$ & $\begin{array}{c}\mathbf{1 9 9 8 - 2 0 0 2} \\
\mathbf{\%}\end{array}$ & $\begin{array}{c}\mathbf{1 9 9 3 - 1 9 9 7} \\
\mathbf{\%}\end{array}$ & $\begin{array}{c}\mathbf{1 9 8 8 - 1 9 9 2} \\
\mathbf{\%}\end{array}$ \\
\hline Librarianship & 64 & 77.1 & 69.4 & 69.2 \\
\hline $\begin{array}{l}\text { Records } \\
\text { management }\end{array}$ & 3 & 3.6 & 3.2 & 10.5 \\
\hline Archives & 0 & 0 & 2.4 & 0 \\
\hline Computing \& IS & 1 & 1.2 & 1.6 & 1.5 \\
\hline $\begin{array}{l}\text { Other information } \\
\text { work }\end{array}$ & 9 & 10.8 & 12.9 & 9.0 \\
\hline $\begin{array}{l}\text { Unconnected with } \\
\text { information }\end{array}$ & 6 & 7.2 & 10.5 & 9.8 \\
\hline Totals & $\mathbf{8 3}$ & $\mathbf{1 0 0 . 0}$ & $\mathbf{1 0 0 . 0}$ & $\mathbf{1 0 0 . 0}$ \\
\hline
\end{tabular}

*Missing cases, including those not currently in work: 5. BA (LCIM) graduates omitted.

Table 8: Type of work, records management graduates

\begin{tabular}{|l|c|c|c|c|}
\hline Type of work & $\begin{array}{c}\mathbf{1 9 9 8 - 2 0 0 2} \\
\boldsymbol{n}\end{array}$ & $\begin{array}{c}\mathbf{1 9 9 8 - 2 0 0 2} \\
\mathbf{\%}\end{array}$ & $\begin{array}{c}\mathbf{1 9 9 3 - 1 9 9 7} \\
\mathbf{\%}\end{array}$ & $\begin{array}{c}\mathbf{1 9 8 8 - 1 9 9 2} \\
\mathbf{\%}\end{array}$ \\
\hline Librarianship & 1 & 4.8 & 6.7 & n.a. \\
\hline $\begin{array}{l}\text { Records } \\
\text { management }\end{array}$ & 14 & 66.7 & 46.7 & n.a. \\
\hline Archives & 5 & 23.8 & 26.7 & n.a. \\
\hline Computing \& IS & 0 & 0 & 13.3 & n.a. \\
\hline $\begin{array}{l}\text { Other information } \\
\text { work }\end{array}$ & 1 & 4.8 & 6.7 & n.a. \\
\hline $\begin{array}{l}\text { Unconnected with } \\
\text { information }\end{array}$ & 0 & 0 & 0 & n.a. \\
\hline Totals & $\mathbf{2 1 *}$ & $\mathbf{1 0 0 . 0}$ & $\mathbf{1 0 0 . 0}$ & \\
\hline
\end{tabular}

*Missing cases, including those not currently in work: 1. BA (LCIM) graduates omitted.

A greater percentage of librarianship graduates than records management graduates find employment outside of the traditional information professions. In all $18 \%$ of librarianship graduates reported having either 'other information work' or work 'unconnected with information'. This was the case for only 1 (4.8\%) records 
management graduate. This may be the result of either the strong demand for records managers or a belief by employers that a librarianship qualification prepares graduates for a wider range of work. Records management graduates do, however, appear to be in high demand within their professional area, with over $90 \%$ in the most recent survey finding work within records management or the cognate occupation of 'archives'.

\section{Professionalism}

Genoni et al., (2000) reported that there was "little variation" in the skill levels in employment for the 1988-92 and 1993-97 surveys, although a reduction in the number of respondents who "described their work as 'unskilled"” was also noted (p. 252). These data together with the 1998-2002 results are shown in Table 9.

Table 9: Current level of professionalism in employment, all graduates

\begin{tabular}{|l|c|c|c|c|}
\hline Level of professionalism & $\begin{array}{c}\mathbf{1 9 9 8 - 2 0 0 2} \\
\mathbf{n}\end{array}$ & $\begin{array}{c}\mathbf{1 9 9 8 - 2 0 0 2} \\
\mathbf{\%}\end{array}$ & $\begin{array}{c}\mathbf{1 9 9 3 - 9 7} \\
\mathbf{\%}\end{array}$ & $\begin{array}{c}\mathbf{1 9 8 8 - 9 2} \\
\mathbf{\%}\end{array}$ \\
\hline Professional/highly skilled & 79 & 73.8 & 72.1 & 72.5 \\
\hline Para-professional/skilled & 23 & 21.5 & 20.8 & 15.9 \\
\hline Semi-skilled & 4 & 3.7 & 6.4 & 8.0 \\
\hline Unskilled & 1 & 0.9 & 0.7 & 3.6 \\
\hline Totals & $\mathbf{1 0 7}^{*}$ & $\mathbf{1 0 0 . 0}$ & $\mathbf{1 0 0 . 0}$ & $\mathbf{1 0 0 . 0}$ \\
\hline
\end{tabular}

* Missing cases (including those not currently in work): 6

These results indicate that the percentage of graduates finding professional level employment has remained consistent over the three surveys. There is an indication of a decline in 'semi-skilled' work which has in turn led to a very small increase in respondents indicating they were engaged in 'para-professional' or 'professional' work.

This data is further examined in Tables 10 and 11.

Table 10: Current level of professionalism in employment, librarianship graduates

\begin{tabular}{|l|c|c|c|c|}
\hline Level of professionalism & $\begin{array}{c}\mathbf{1 9 9 8 - 2 0 0 2} \\
\boldsymbol{n}\end{array}$ & $\begin{array}{c}\mathbf{1 9 9 8 - 2 0 0 2} \\
\mathbf{\%}\end{array}$ & $\begin{array}{c}\mathbf{1 9 9 3 - 1 9 9 7} \\
\mathbf{\%}\end{array}$ & $\begin{array}{c}\mathbf{1 9 8 8 - 1 9 9 2} \\
\mathbf{\%}\end{array}$ \\
\hline $\begin{array}{l}\text { Professional/ highly } \\
\text { skilled }\end{array}$ & 59 & 71.1 & 70.5 & 72.5 \\
\hline Para-professional/ skilled & 19 & 22.9 & 21.3 & 15.9 \\
\hline Semi-skilled & 4 & 4.8 & 7.3 & 8.0 \\
\hline Unskilled & 1 & 1.2 & 0.8 & 3.6 \\
\hline Totals & $\mathbf{8 3}^{*}$ & $\mathbf{1 0 0 . 0}$ & $\mathbf{1 0 0 . 0}$ & $\mathbf{1 0 0 . 0}$ \\
\hline
\end{tabular}

*Missing cases, including those not currently in work: 5. BA (LCIM) graduates omitted. 
Genoni, P. \& Smith, K. (2005, November). Results of the longitudinal study of employment outcomes for Australian ILS graduates. The Australian Library Journal. 54(4) 336-352

Table 11: Current level of professionalism in employment, records management graduates

\begin{tabular}{|l|c|c|c|c|}
\hline Level of professionalism & $\begin{array}{c}\mathbf{1 9 9 8 - 2 0 0 2} \\
\boldsymbol{n}\end{array}$ & $\begin{array}{c}\mathbf{1 9 9 8 - 2 0 0 2} \\
\mathbf{\%}\end{array}$ & $\begin{array}{c}\mathbf{1 9 9 3 - 1 9 9 7} \\
\mathbf{\%}\end{array}$ & $\begin{array}{c}\mathbf{1 9 8 8 - 1 9 9 2} \\
\mathbf{\%}\end{array}$ \\
\hline $\begin{array}{l}\text { Professional/ highly } \\
\text { skilled }\end{array}$ & 19 & 90.5 & 75.0 & n.a. \\
\hline Para-professional/ skilled & 2 & 9.5 & 25.0 & n.a. \\
\hline Semi-skilled & 0 & 0.0 & 0.0 & n.a. \\
\hline Unskilled & 0 & 0.0 & 0.0 & n.a. \\
\hline Totals & $\mathbf{2 1} *$ & $\mathbf{1 0 0 . 0}$ & $\mathbf{1 0 0 . 0}$ & \\
\hline
\end{tabular}

*Missing cases, including those not currently in work: 1. BA (LCIM) graduates omitted.

The data in Tables 10 and 11 indicate that the growth in 'professional' work recorded has derived from records management graduates in particular. This conclusion needs to be treated with caution as it is based on small numbers, but it is likely that the results measure both an increased acceptance of Curtin University's qualifications for records managers, and an increase in the general level of 'professionalism' associated with these jobs.

\section{Nature of employment contract}

A further question about current employment asked respondents to indicate if they were employed on a 'permanent' or some more limited-term basis. The first two surveys suggested a lack of support for the anecdotally popular view that the rate of permanent employment was declining in the Australian workforce, with a corresponding increase in the amount of contract or casual work. Indeed a 'remarkable consistency' was noted in the figures from the 1988-92 and 1993-97 surveys (Genoni et al., 2000, p. 252).

Table 12: Nature of employment contract, all graduates

\begin{tabular}{|l|c|c|c|c|}
\hline Nature of employment & $\begin{array}{c}\mathbf{1 9 9 8 - 2 0 0 2} \\
\boldsymbol{n}\end{array}$ & $\begin{array}{c}\mathbf{1 9 9 8 - 2 0 0 2} \\
\mathbf{\%}\end{array}$ & $\begin{array}{c}\mathbf{1 9 9 3 - 1 9 9 7} \\
\mathbf{\%}\end{array}$ & $\begin{array}{c}\mathbf{1 9 8 8 - 1 9 9 2} \\
\mathbf{\%}\end{array}$ \\
\hline Permanent/ tenured & 87 & 81.3 & 70.9 & 70.9 \\
\hline Limited term contract & 13 & 12.1 & 23.4 & 21.6 \\
\hline Casual & 7 & 5.6 & 5.7 & 7.5 \\
\hline Totals & $\mathbf{1 0 7} *$ & $\mathbf{1 0 0 . 0}$ & $\mathbf{1 0 0 . 0}$ & $\mathbf{1 0 0 . 0}$ \\
\hline
\end{tabular}

*Missing cases, including those not currently in work: 6

The data from the most recent survey suggests that the level of permanent/tenured employment has increased in these five years: up from $70.9 \%$ in $1993-97$ to $81.3 \%$ in 1998-2002, and that limited term contracts have fallen commensurately. The trend in casual employment remained virtually unchanged over the two most recent survey periods: $5.7 \%$ in $1993-97$, and $5.6 \%$ in $1998-2002$. These results therefore indicate that the resistance to casualisation in the information workforce remains strong, and that indeed there is evidence of a shift towards permanency rather than contract employment. 


\section{Employment history}

Casualisation in employment may, however, be exhibited in other ways, and respondents were also asked to describe the continuity of their employment history since their course completion. Evidence of the continuity of employment can be seen in the responses to this question as shown in Table 13.

Table 13: Continuity of employment, all graduates

\begin{tabular}{|l|c|c|c|c|}
\hline Continuity of employment & $\begin{array}{c}\mathbf{1 9 9 8 -} \\
\mathbf{2 0 0 2} \\
\boldsymbol{n}\end{array}$ & $\begin{array}{c}\mathbf{1 9 9 8 - 2 0 0 2} \\
\mathbf{\%}\end{array}$ & $\begin{array}{c}\mathbf{1 9 9 3 - 1 9 9 7} \\
\mathbf{\%}\end{array}$ & $\begin{array}{c}\mathbf{1 9 8 8 - 1 9 9 2} \\
\mathbf{\%}\end{array}$ \\
\hline Continuously employed & 94 & 83.2 & 78.8 & 60.3 \\
\hline $\begin{array}{l}\text { Casual, but fairly } \\
\text { continuously employed }\end{array}$ & 11 & 9.7 & 7.7 & 14.1 \\
\hline $\begin{array}{l}\text { Initially difficult, eventually } \\
\text { employed continuously }\end{array}$ & 2 & 1.8 & 6.4 & 10.3 \\
\hline $\begin{array}{l}\text { Long undesired periods of } \\
\text { unemployment }\end{array}$ & 5 & 4.4 & 3.8 & 12.2 \\
\hline Continuously unemployed & 0 & 0 & 2.6 & 1.3 \\
\hline Not actively seeking work & 1 & 0.9 & 0.7 & 1.9 \\
\hline Totals & $\mathbf{1 1 3}$ & $\mathbf{1 0 0 . 0}$ & $\mathbf{1 0 0 . 0}$ & $\mathbf{1 0 0 . 0}$ \\
\hline
\end{tabular}

There has been a marked increase in the 'continuously employed' category for the new graduate respondents since the first survey, from $60.3 \%$ to $83.2 \%$. When this is combined with the other categories indicating continuous or 'fairly continuous' employment, the results rise from 84.7\% (1988-92), to 92.9\% (1993-97) and 94.7\% (1998-2002). The category 'casual, but fairly continuously employed' recorded a slight shift towards casual employment, with a change from $7.7 \%$ in $1993-97$, to $9.7 \%$ in the 1998-2002 data. Both figures, however, are well below the $14.1 \%$ reported for 1988-92. It is also worth noting that the current survey is the first to find no respondents reporting that they had experienced continuous unemployment.

Table 14: Continuity of employment, librarianship graduates

\begin{tabular}{|l|c|c|c|c|}
\hline Coninuity of employment & $\begin{array}{c}\mathbf{1 9 9 8 - 2 0 0 2} \\
\mathbf{n}\end{array}$ & $\begin{array}{c}\mathbf{1 9 9 8 - 2 0 0 2} \\
\mathbf{\%}\end{array}$ & $\begin{array}{c}\mathbf{1 9 9 3 - 1 9 9 7} \\
\mathbf{\%}\end{array}$ & $\begin{array}{c}\mathbf{1 9 8 8 - 1 9 9 2} \\
\mathbf{\%}\end{array}$ \\
\hline Continuously employed & 72 & 81.8 & 80 & 60.3 \\
\hline $\begin{array}{l}\text { Casual, but fairly } \\
\text { continuously employed }\end{array}$ & 8 & 9.1 & 7.5 & 14.1 \\
\hline $\begin{array}{l}\text { Initially difficult, eventually } \\
\text { employed continuously }\end{array}$ & 2 & 2.3 & 6.7 & 10.3 \\
\hline $\begin{array}{l}\text { Long undesired periods of } \\
\text { unemployment }\end{array}$ & 5 & 5.7 & 3.7 & 12.2 \\
\hline Continuously unemployed & 0 & 0.0 & 1.5 & 1.3 \\
\hline Never sought work & 1 & 1.1 & 0.7 & 1.9 \\
\hline Totals & $\mathbf{8 8} *$ & $\mathbf{1 0 0 . 0}$ & $\mathbf{1 0 0 . 0}$ & $\mathbf{1 0 0 . 0}$ \\
\hline
\end{tabular}

* No missing cases, BA(LCIM) graduates omitted 
The librarianship graduates who have been employed 'continuously' or 'fairly continuously' improved from 84.7\% (1988-92), to 94.2\% (1993-97), and 93.2\% (1998-2002). The real improvement, however, has been in the measure of those who found employment 'initially difficult [but] eventually continuously employed'. The current survey records continuing decline in this figure, down to $2.3 \%$ in the current survey. This indicates a far more rapid uptake of library graduates into the workforce.

Table 15: Continuity of employment, records management graduates

\begin{tabular}{|l|c|c|c|c|}
\hline Continuity of employment & $\begin{array}{c}\mathbf{1 9 9 8 - 2 0 0 2} \\
\boldsymbol{n}\end{array}$ & $\begin{array}{c}\mathbf{1 9 9 8 - 2 0 0 2} \\
\mathbf{\%}\end{array}$ & $\begin{array}{c}\mathbf{1 9 9 3 - 1 9 9 7} \\
\mathbf{\%}\end{array}$ & $\begin{array}{c}\mathbf{1 9 8 8 - 1 9 9 2} \\
\mathbf{\%}\end{array}$ \\
\hline Continuously employed & 20 & 90.9 & 68.4 & n.a. \\
\hline $\begin{array}{l}\text { Casual, but fairly } \\
\text { continuously employed }\end{array}$ & 2 & 9.1 & 10.5 & n.a. \\
\hline $\begin{array}{l}\text { Initially difficult, eventually } \\
\text { employed continuously }\end{array}$ & 0 & 0.0 & 5.3 & n.a. \\
\hline $\begin{array}{l}\text { Long undesired periods of } \\
\text { unemployment }\end{array}$ & 0 & 0.0 & 5.3 & n.a. \\
\hline Continuously unemployed & 0 & 0.0 & 10.5 & n.a. \\
\hline Never sought work & 0 & 0.0 & 0 & n.a. \\
\hline Totals & $\mathbf{2 2 *}$ & $\mathbf{1 0 0 . 0}$ & $\mathbf{1 0 0 . 0}$ & \\
\hline
\end{tabular}

* No missing cases, BA(LCIM) graduates omitted

The results for records management graduates should be treated with some caution due to the low number of participants, but for the recent survey period all respondents had experienced either continuous or near continuous employment. This accords with anecdotal evidence which indicates a heavy demand for skilled and qualified workers in this area, and represents a marked improvement over the previous survey period.

The employment history of graduates was also investigated in a further question, in which respondents were asked to describe the nature of the 'majority' of their employment since graduation. This question also related the employment to 'information-related work' and the results are shown in Table 16. 
Genoni, P. \& Smith, K. (2005, November). Results of the longitudinal study of employment outcomes for Australian ILS graduates. The Australian Library Journal. 54(4) 336-352

Table 16: Majority of post-graduation employment, all graduates

\begin{tabular}{|l|c|c|c|c|}
\hline \multicolumn{1}{|c|}{ Type of employment } & $\begin{array}{c}\mathbf{1 9 9 8 - 2 0 0 2} \\
\mathbf{n}\end{array}$ & $\begin{array}{c}\mathbf{1 9 9 8 - 2 0 0 2} \\
\mathbf{\%}\end{array}$ & $\begin{array}{c}\mathbf{1 9 9 3 - 9 7} \\
\mathbf{\%}\end{array}$ & $\begin{array}{c}\mathbf{1 9 8 8 - 9 2} \\
\mathbf{\%}\end{array}$ \\
\hline $\begin{array}{l}\text { Professional information } \\
\text { work }\end{array}$ & 78 & 69.6 & 62.4 & 64.4 \\
\hline $\begin{array}{l}\text { Para-professional } \\
\text { information work }\end{array}$ & 21 & 18.8 & 21.5 & 16.1 \\
\hline $\begin{array}{l}\text { Non-professional } \\
\text { information work }\end{array}$ & 5 & 4.5 & 6.0 & 7.4 \\
\hline $\begin{array}{l}\text { Non-information } \\
\text { professional }\end{array}$ & 7 & 6.3 & 4.7 & 5.4 \\
\hline $\begin{array}{l}\text { Non-information } \\
\text { non-professional }\end{array}$ & 1 & 0.9 & 5.4 & 6.7 \\
\hline Totals & $\mathbf{1 1 2} *$ & $\mathbf{1 0 0}$ & $\mathbf{1 0 0}$ & $\mathbf{1 0 0}$ \\
\hline
\end{tabular}

*Missing cases: 1

This data indicates that the nearly $70 \%$ of graduates have been mostly employed in professional information work, and an additional 6.3\% in professional positions not related to information work. Despite the fact that these figures represent an improvement in both categories when compared to previous surveys, these results might still be considered disappointing if its is assumed that all graduates were hoping to obtain professional information work at the completion of their study.

It is however likely, and indeed probable, that some graduates have been content to remain in a 'para-professional' or 'non-professional' position they occupied while studying. Students may commence a course with an intention of gaining additional security in their present job or to prepare for some later career move, rather than with the intention of immediately gaining a fully professional appointment.

\section{Course experience}

Graduate reaction to courses is important to the academic community, both in their response to quality of the educational experience and the outcome of the acquired skills and qualification on graduates employment prospects. The survey sought information on these issues with a series of questions, one of which asked respondents to indicate the contribution their qualification had made to obtaining their current employment. Results are shown in Table 17. 
Genoni, P. \& Smith, K. (2005, November). Results of the longitudinal study of employment outcomes for Australian ILS graduates. The Australian Library Journal. 54(4) 336-352

Table 17: Contribution of qualification to obtaining current employment

\begin{tabular}{|c|c|c|c|c|}
\hline $\begin{array}{l}\text { Contribution of } \\
\text { qualification }\end{array}$ & $\begin{array}{c}\text { 1998-2002 } \\
n\end{array}$ & $\begin{array}{c}1998-2002 \\
\%\end{array}$ & $\begin{array}{c}1993-1997 \\
\% \\
\end{array}$ & $\begin{array}{c}1988-1992 \\
\%\end{array}$ \\
\hline Essential & 77 & 72.6 & 64.8 & 67.9 \\
\hline $\begin{array}{l}\text { Not essential, but } \\
\text { helped }\end{array}$ & 21 & 19.8 & 15.5 & 16.8 \\
\hline $\begin{array}{l}\text { Any degree was } \\
\text { essential }\end{array}$ & 0 & 0.0 & 1.4 & 1.5 \\
\hline $\begin{array}{l}\text { Helped } \\
\text { marginally }\end{array}$ & 3 & 2.8 & 5.6 & 6.9 \\
\hline Irrelevant & 5 & 4.7 & 12.7 & 6.9 \\
\hline Totals & 106* & 100.0 & 100.0 & 100.0 \\
\hline
\end{tabular}

The data in Table 17 reveal that the most recent survey produced the most favourable outcome in terms of the contribution made by the qualification to winning employment. The combined measures of 'helped marginally' and 'irrelevant' declined from $18.3 \%$ of respondents for $1993-97$, to $7.5 \%$ in $1998-2002$.

Respondents were also asked to reflect on the usefulness of the skills they acquired during their course to their current employment (this question was not included in the 1988-1992 survey).

Table 18: Usefulness of skills to current employment

\begin{tabular}{|l|c|c|c|}
\hline Usefulness of skills & $\begin{array}{c}\mathbf{1 9 9 8 - 2 0 0 2} \\
\mathbf{n}\end{array}$ & $\begin{array}{c}\mathbf{1 9 9 8 - 2 0 0 2} \\
\mathbf{\%}\end{array}$ & $\begin{array}{c}\mathbf{1 9 9 3 - 1 9 9 7} \\
\mathbf{\%}\end{array}$ \\
\hline Very useful & 50 & 47.7 & 38.1 \\
\hline Moderately useful & 45 & 42.1 & 38.1 \\
\hline Occasionally useful & 10 & 9.3 & 20.9 \\
\hline Not relevant & 2 & 1.9 & 2.9 \\
\hline Totals & $\mathbf{1 0 7}^{*}$ & $\mathbf{1 0 0}$ & $\mathbf{1 0 0}$ \\
\hline
\end{tabular}

*Missing cases (including those not currently in work): 6

There is an increase in the measure of the usefulness of the skills taught between the two survey periods. In the current survey $89.8 \%$ of respondents found the skills they obtained either 'very useful' or 'moderately useful'. These categories combined in the previous survey accounted for $76.2 \%$ of responses.

The responses recorded in Tables 17 and 18 may reflect some changes to the curriculum which have increased the utility of the course for employment purposes and course content which is more relevant to the workplace. Just as likely, however, is that these responses are a reflection of the improved employment situation recorded in Tables 5, 12 and 13, with a greater percentage of respondents in satisfactory employment than reported in previous surveys.

Graduate satisfaction is a very important element in any teaching program, and may reflect a different response to the course than implied by the employment outcome. 
The final question of the survey asked: "which of the following statements best describes the feelings about your qualifying course...?" (this question was not included in the 1988-1992 survey).

Table 19: Feelings about qualifying course

\begin{tabular}{|l|c|c|c|}
\hline \multicolumn{1}{|c|}{ Feelings } & $\begin{array}{c}\mathbf{1 9 9 8 - 2 0 0 2} \\
\boldsymbol{n}\end{array}$ & $\begin{array}{c}\mathbf{1 9 9 8 - 2 0 0 2} \\
\mathbf{\%}\end{array}$ & $\begin{array}{c}\mathbf{1 9 9 3 - 9 7} \\
\mathbf{\%}\end{array}$ \\
\hline $\begin{array}{l}\text { Very glad I did the } \\
\text { course }\end{array}$ & 86 & 76.1 & 78.8 \\
\hline Partly satisfied & 24 & 21.2 & 17.3 \\
\hline $\begin{array}{l}\text { Wish I had not } \\
\text { done the course }\end{array}$ & 3 & 2.7 & 3.8 \\
\hline Totals & $\mathbf{1 1 3}$ & $\mathbf{1 0 0 . 0}$ & $\mathbf{1 0 0 . 0}$ \\
\hline
\end{tabular}

There is little change in responses to this question between the two surveys with a generally high level of satisfaction being recorded.

In the report on the previous survey Genoni et al., (2000) reported that there was "a lower level of satisfaction expressed with graduate diploma courses" and suggested that this could be because of the "nature of the teaching and study required in order for the course to be completed on one academic year" (p. 257). This difference was not, however, evident in the most recent survey, wherein $75.4 \%$ of bachelor level graduates and $77.1 \%$ of graduate diploma graduates indicated they were 'very glad' they did the course. Results for the 'very glad' reponse were also similar for librarianship (75\%) and records management (77.3\%) graduates.

Study since graduation

Respondents were asked to indicate if they had undertaken any further formal study since completing their professional qualification. The results to this question are shown in Table 20.

Table 20: Study undertaken since graduation

\begin{tabular}{|l|c|c|c|c|}
\hline $\begin{array}{c}\text { Study since } \\
\text { graduation }\end{array}$ & $\begin{array}{c}\mathbf{1 9 9 8 - 2 0 0 2} \\
\boldsymbol{n}\end{array}$ & $\begin{array}{c}\mathbf{1 9 9 8 - 2 0 0 2} \\
\mathbf{\%}\end{array}$ & $\begin{array}{c}\mathbf{1 9 9 3 - 9 7} \\
\mathbf{\%}\end{array}$ & $\begin{array}{c}\mathbf{1 9 8 8 - 9 2} \\
\mathbf{\%}\end{array}$ \\
\hline Yes & 29 & 25.7 & 23.1 & 28 \\
\hline No & 84 & 74.3 & 76.9 & 72 \\
\hline Totals & $\mathbf{1 1 3}$ & $\mathbf{1 0 0}$ & $\mathbf{1 0 0}$ & $\mathbf{1 0 0}$ \\
\hline
\end{tabular}

The result for those who have undertaken further study since graduation is generally in line with those of the previous surveys. Of the 29 who had indicated they had undertaken further study, 25 provided a description of that study. Nine of these had gone on to higher education in the ILS field (8 masters and 1 honours). Other common choices included management/administration (5) and computing/ multimedia (3). Other choices were apparently unrelated to ILS and included nursing, occupational health and safety and applied linguistics. These choices may in some cases, still be related to an information related career. For example, the graduate who 
undertook further study in nursing is now working as a 'medical researcher', a career which clearly marries the two streams of his/her academic background.

\section{Conclusions}

The survey reported above, covering graduates from 1998-2002, indicates an encouraging outcome with regard to the employment prospects of LIS graduates. Although the period covered by the survey witnessed continuing concern about the future of the profession and the job prospects of graduates, repondents to this survey had generally fared better than those in the previous two surveys. Although the measureable changes have been subtle rather than dramatic, there have nevertheless been improvements in terms of the percentages of graduates finding jobs, finding professional level positions and finding permanent employment in their postgraduation phase. The indicators are particularly good for records management graduates, but also record an improvement for library studies graduates.

The results indicate that a number of graduates continue to find their way into information related jobs outside libraries and records centres. In this the Curtin University data offer a comparison with a recent study carried out for similar courses at the University of New South Wales (Willard et al., 2003) which reported that "while the bulk of their graduate positions were in libraries and information centres ... there were also positions which indicated less mainstream library and information activities" (p. 209). It is not clear whether this is by choice or necessity, but it does at least suggest that what LIS educators proclaim is indeed the case; that is, that the qualification provides important generic skills that are adaptable to 'non-traditional' occupations.

It is, however, reasonable to sound some caution. It should be noted that Curtin University is now qualifying fewer LIS graduates. For example, the 1988-1992 survey was sent 419 graduates, all of whom were qualified to practise as librarians. The 1998-2002 survey was sent to 338 graduates of whom 289 were qualified to practise as librarians. Clearly employment outcomes reflect supply as well as demand, and the supply from Curtin University is less than it has been in the past.

In addition, the wider employment situation has improved in Australia across the course of the three surveys. The period covered by the first survey coincided with an economic recession and high unemployment, which rose from $6.5 \%$ in 1988 to just over 10\% during 1993 (Wilkins, 2004). Unemployment has gradually returned to more historically 'normal' levels over the ensuing decade. In August 2003 it was officially 5.8\% and by March 2005 was 5.1\% (ABS, 2005a). The most recent survey was therefore conducted against a background of steadily improving employment.

The ABS currently rates the job prospects for librarians as 'average', with an expectation of a 'decline' in positions over the next five years (ABS, 2005b). They envisage that $88 \%$ of jobs will be created by movement in the sector, and $12 \%$ by workers leaving the occupation. The ABS anticipated growth in the number of new jobs to be created for librarians is a dispiriting $0 \%$. The ABS outlook for records managers is more optimistic, with job prospects rated as 'good', and with an anticipated $8 \%$ of job opportunities being the result of new positions being created (ABS, 2005b). 
An important underlying issue is the ageing library workforce. Although this problem occurs other sectors of the workforce, the 1998 report prepared for ALIA by the Australian Centre for Industrial Relations Research and Training concluded that 'library workers are considerably older than both the public sector and labour force averages (ACIRRT, 1998, p. 7). There are therefore reasons to be particularly concerned about the issue in the information professions, and as the data reported in this paper indicates the library workforce is already 'ageing' when it graduates from courses at Curtin University. Ongoing concern regarding the ageing workforce has recently prompted the libraries of the Australian Technology Network (ATN) to undertake a study of the issue (Whitmell \& Assoc., 2004) and how they might position themselves to cope with the "looming demographic crisis" (p. 2).

The problem of the ageing workforce has several implications for the training and employment of library staff. The most obvious of these is the longterm capacity of an occupational group to replace itself when new entrants are frequently commencing a twenty year career rather than a thirty or forty year career. In periods of high general unemployment abbreviated career spans might assist in maintaining employment within a sector, but if the economy enters a prolonged period of comparatively high employment then that sector may inevitably face a labour shortage.

Some of the recommendations of the Whitmell \& Assoc. report point to additional problems which have beset higher education generally. These include the often rapid obsolescence of skills and knowledge acquired in first qualifying degrees. One of the possible solutions to this problem is advocated in a recommendation which stresses the need for libraries to plan "to continue to develop the skills, attitudes, and approaches of staff” (p. 13). It is notable from the three surveys conducted of Curtin University graduates, however, that the participation rate in further formal education has remained almost unchanged. This is a slightly disheartening result, although it needs to be borne in mind that the survey covers the years immediately after commencing work when many respondents would be establishing their career and repaying their education related debt. As one respondent noted in regard to the question about whether he/she had undertaken further study; 'No, but only because access to affordable study has been severely curtailed since 1996 due to political circumstances'.

It should also be remembered that the figures reported above are indicative of trends in early career employment only. Although it is encouraging that graduates are finding more satisfying employment outcomes than was the case in previous years, this does not of course provide a full picture of their career trajectory or expectations.

Despite several reservations, however, the survey results provide reasons to be cautiously optimistic. They represent a picture of librarianship as a profession which is experiencing a strong demand for recently qualified practitioners, and in which graduates have an excellent chance of finding full employment at a level commensurate with their qualifications. The long term view is, however, more worrying, in that it would appear that the current strong demand may be underwritten by falling student numbers and retirements, rather than by genuine jobs growth. 
Genoni, P. \& Smith, K. (2005, November). Results of the longitudinal study of employment outcomes for Australian ILS graduates. The Australian Library Journal. 54(4) 336-352

\section{References}

Aina, L.O. \& Moahi, K. (1999). 'Tracer study of the Botswana library school graduates’. Education for Information. 17 (3): 215-245.

Australian Bureau of Statistics (ABS). (2005a). ABS 6202: Labour Force, Australia, March 2005. http://www.abs.gov.au/Ausstats/abs@nsf./0/

Australian Bureau of Statistics (ABS). (2005b). Australian Careers: Librarians. http://jobsearch.gov.au/joboutlook/default.aspx?PageId=AscoDesc\&AscoCode=2292

Australian Centre for Industrial Relations Research and Training (ACCIRT) (1998). Profile of Australian library workers. Sydney: ACCIRT.

Genoni, P., Exon, M., Farrelly, K. (2000). 'Graduate employment outcomes for qualifying library and records management courses at Curtin University of Technology’. Australian Library Journal, 49 (3): 245-258.

Marcella, R., \& Baxter, G. (1998). 'A career progression survey of graduates of the Postgraduate Diploma/MSc in Information Analysis'. Education for Information, 16 (2): 107-130.

Moreiro, J.A. (2001). 'Figures on employability of Spanish library and information science graduates’. Libri, 51 (1): 27-37.

Pember, M. (2003). 'A decade of recordkeeping education at Curtin University of Technology: flux and flexibility’. Australian Library Journal, 52 (1): 65-79

Whitmell \& Associates (2004). Preparing for Demographic Change: Workforce and Succession Planning in the Libraries of the Australian Technology Network. http://www.atn.edu.au/docs/LATN\%20Workforce\%20and\%20Succession\%20Planni ng\%20.pdf

Wilkins, R. (2004). The Extent and Consequences of Underemployment in Australia. Melbourne Institute Working Paper No. 16/04. Melbourne: Melbourne Institute of Applied Economic and Social Research.

Willard, P., Wilson, C., Cole, F. (2003) 'Changing employment patterns: An Australian experience’, Education for Information, 21 (4): 209-227.

Yakel, E. (2003). The future of the past: a survey of graduates of master's-level archival education programs in the United States. The American Archivist. 63: $301-$ 321.

\section{Dr Paul Genoni}

Paul Genoni is a Senior Lecturer with the Department of Media and Information at Curtin University of Technology. His major teaching areas are reference work, 
Genoni, P. \& Smith, K. (2005, November). Results of the longitudinal study of employment outcomes for Australian ILS graduates. The Australian Library Journal. 54(4) 336-352

collection management and digital libraries, and he is currently engaged in research on the efficacy of e-research. He has also published widely on Australian literature, in particular $20^{\text {th }}$ century fiction.

\section{Dr Kerry Smith}

Kerry Smith is Head of the Department of Media \& Information at Curtin University of Technology. She teaches in library management, one person libraries and knowledge management. Her current research interests are in science and technology information policy specialising in the geosciences and she is also a participant in two current IFLA research projects. She has been editor-in-chief of the electronic journal LIBRES (Library and Information Science Research) since 1996, was the President of the Australian Library and Information Association (ALIA) in 1997, is a Fellow of ALIA and currently chairs the Library Theory and Research Section of the International Federation of Library Associations \& Institutions (IFLA). 